Original Paper

\title{
Pendampingan Masyarakat dalam Pengolahan Limbah Peternakan Sapi untuk Meningkatkan Pertumbuhan Tanaman
}

\author{
Ahmad Raksun ${ }^{1}$, Lalu Zulkifli ${ }^{1}$, Mahrus ${ }^{1}$, Lalu Japa ${ }^{1}$, Prapti Sedijani ${ }^{1}$ \\ ${ }^{1}$ Program Studi Pendidikan Biologi, Fakultas Keguruan dan Ilmu Pendidikan \& Pascasarjana, Universitas Mataram, \\ Indonesia
}

DOI: $10.29303 /$ jpmpi.v2i1.351

Sitasi: Raksun, A., Zulkifli, L., Mahrus., Japa, L., Sedijani, P. (2019). Pendampingan Masyarakat dalam Pengolahan Limbah Peternakan Sapi untuk Meningkatkan Pertumbuhan Tanaman. Jurnal Pengabdian Magister Pendidikan IPA (JPMPI). (2) 1. pp. xx

*Corresponding Author: Ahmad Raksun, Program Studi Pendidikan Biologi, Fakultas Keguruan dan Ilmu Pendidikan Universitas Mataram, Indonesia;

Email:

ahmadraksun@unram.ac.id

\begin{abstract}
Pengabdian pada masyarakat ini telah dilaksanakan di Desa Jatisela Kecamatan Gunung Sari Kabupaten Lombok Barat Propinsi Nusa Tenggara Barat. Sebagian masyarakat Desa Jatisela yang bermatapencaharian sebagai petani, kuhusnya yang berdomisili di Dusun Ireng Daye memiliki usaha sampingan yaitu beternak sapi, kuda dan kambing. Mereka membentuk kelompok ternak yang disebut Kelompok Ternak Patuh Angen. Kegiatan peternakan sapi yang dilakukan oleh Kelompok Ternak Patuh Angen menghasilkan limbah berupa kotoran ternak dan sisa makanan ternak. Peternak sapi di Dusun Ireng Daye belum menemukan alternatif pemecahan masalah limbah peternakan sapi yang ada di sekitar tempat tinggal mereka. Pengolahan limbah peternakan sapi menjadi pupuk organik merupakan alternatif pemecahan masalah yang dapat diterapkan untuk mengatasi permasalahan yang mereka hadapi. Pupuk organik yang dihasilkan dapat dijadikan pupuk untuk meningkatkan hasil panen tanaman. Adapun tahapan kerja pengolahan limbah peternakan sapi menjadi bokashi dan pemanfatannya pada lahan pertanian adalah sebagai berikut: (1) sosialisasi kegiatan, (2) penyampaian materi tentang kebersihan lingkungan, cara pembuatan bokashi dan manfaat bokashi untuk pertumbuhan tanaman, (3) pembuatan bokashi, (3) penggunaan bokashi pada lahan pertanian. Metotode yang digunakan adalah metode ceramah, diskusi, pelatihan dan pendampingan. Dalam pelaksanaan kegiatan ini nampak bahwa masyarakat yang menjadi mitra kegiatan telaah mengikuti kegiatan dengan baik mulai dari sosialisasi kegiatan sampai pada kegiatan terakhir pelaksanaan pengabdian. Hal ini dapat dilihat dari banyaknya pertanyaan yang diajukan peserta yang terkait dengan materi yang disampaikan tim pelaksana pada saat diskusi. Selain itu pada saat praktek pembuatan bokashi semua peserta ikut bekerja secara aktif sehingga kegiatan paraktek pembuatan bokashi dapat berjalan lancer.
\end{abstract}

Kata Kunci: Pendampingan masyarakat; pengelolaan limbah; peternakan sapi; pertumbuhan tanaman.

\section{Pendahuluan}

Desa Jatisela adalah salah satu desa yang ada dalam wilayah Kecamatan Gunung Sari Kabupaten Lombok Barat Propinsi Nusa Tenggara Barat. Di Desa Jatisela terdapat lima dusun yaitu Dusun Jati Ireng, Dusun Ireng Lauk, Dusun Ireng Daye, Dusun Montong Pace dan Dusun Kebon Talo. Masyarakat
Desa Jatisela sebagian besar hidup sebagai petani dan sebagian kecil lainnya hidup sebagi nelayan, pegawai negeri sipil, pedagang, buruh tani, pengerajin dan tukang bangunan. Masyarakat Desa Jatisela yang hidup sebagai petani, nelayan, buruh tani, pengerajin dan tukang bangunan masih tergolong masyarakat miskin karena memiliki penghasilan yang rendah. 
Sebagian masyarakat Desa Jatisela yang bermatapencaharian sebagai petani, kuhusnya yang berdomisili di Dusun Ireng Daye memiliki usaha sampingan yaitu beternak sapi, kuda dan kambing. Kelompok masyarakat yang memiliki ternak membentuk kelompok ternak yang disebut Kelompok Ternak Patuh Angen. Ternak sapi masyarakat tani Dusun Ireng Daye dipelihara dengan cara dikandangkan pada sebuah kandang kolektif yang ada ditengah perkampungan masyarakat Dusun Ireng Daye. Para peternak memelihara sapi untuk dikembangbiakkan, setelah jumlah sapi menjadi banyak maka sebagian akan dijual untuk memenuhi keutuhan hidup sehari-hari. Kegiatan peternakan sapi yang dilakukan oleh masyarakat tani Dusun Ireng Daye menghasilkan limbah berupa kotoran ternak dan sisa makanan ternak. Banyaknya kotoran ternak dan sisa makanan ternak di lingkungan sekitar Dusun Ireng Daye menyebabkan terjadinya masalah lingkungan karena ditangani dengan cara yang tidak bijaksana. Limbah peternakan yang berupa sisa makanan dan kotoran ternak biasanya ditumpuk di sekitar kandang ternak. Sebagian sisa makanan ternak dimusnahkan dengan cara dibakar sedangkan sebagian kotoran ternak dibuang ke kali sehingga menyebabkan terjadinya pencemaran air kali di sekitar Dusun Ireng Daye.

Peternak sapi di Dusun Ireng Daye belum menemukan alternatif pemecahan masalah limbah peternakan sapi yang ada di sekitar tempat tinggal mereka. Pengolahan limbah peternakan sapi menjadi pupuk organik merupakan alternatif pemecahan masalah yang dapat diterapkan untuk mengatasi permasalahan yang dihadapi peternak sapi Dusun Ireng Daye. Pupuk organik yang dihasilkan dapat dijadikan pupuk untuk meningkatkan hasil panen tanaman. Selain itu bokashi juga dapat dijual kepada petani lain sehingga dapat menjadi sumber pendapatan baru bagi masyarakat peternak sapi Dusun Ireng Daye

Berdasarkan uraian di atas maka kami tim pelaksana pengabdian pada masyarakat Universitas Mataram, berupaya menjadikan masyarakat tani Dusun Ireng Daye yang memiliki ternak sapi sebagai mitra pelaksanaan pengabdian pada masyarakat. Permasalahan utama yang dihadapi oleh mitra, yaitu: (1) mitra belum menemukan alternatif pemecahan masalah limbah yang dihasilkan dari kegiatan peternakan sapi, (2) mitra tidak memiliki pengetahuan dan keterampilan dalam mengolah limbah peternakan sapi menjadi produk yang bernilai ekonomi, (3) pengetahuan mitra tentang teknik pemupukan tanaman masih rendah.

\section{Metode Pelaksanaan}

Pemecahan masalah mitra dilakukan dengan mengolah limbah peternakan sapi menjadi bokashi. Bokashi adalah kompos yang dihasilkan melaui fermentasi dengan pemberian Effective Microorganism 4 (EM4), yang merupakan salah satu aktivator untuk mempercepat proses pembuatan kompos (Indriani, 2001). Kegiatan pengolahan limbah peternakan sapi menjadi bokashi dilakukan dengan teknologi biofermentasi EM4. Metode yang digunakan adalah ceramah, diskusi, pelatihan dan pendampingan. Adapun tahapan kerja pengolahan limbah peternakan sapi menjadi bokashi dan pemanfatannya pada lahan pertanian adalah sebagai berikut:

1) Sosialisasi: kegiatan sosialisasi dilakukan kepada kepala dusun, ketua RT dan masyarakat tani Dusun Ireng Daye yang memiliki ternak sapi (mitra kegiatan pengabdian). Kegiatan sosialisasi dilakukan dengan metode ceramah dan diskusi

2) Pembuatan bokashi: pembuatan bokashi dilakukan dengan bahan baku sisa makanan ternak dan kotoran ternak yang dicampur dengan sekam dan dedak halus. Selanjutnya campuran tersebut dibasahi dengan larutan gula EM4. Campuran bahan baku bokashi difermentasi selama 30 hari pada bak fermentasi. Kegiatan pembuatan bokashi dilakukan dengan metode ceramah dan pelatihan.

3) Penggunaan bokashi pada lahan pertanian: uji coba penggunaan bokashi dilakukan pada lahan yang mudah dilihat oleh masyarakat.

Pemeliharaan Tanaman: uji coba penggunaan bokashi yang dilakukan pada tanaman cabai rawit dan kacang panjang. Kegiatan pemeliharaan tanaman meliputi pemeliharaan bibit, penyiangan tanaman, pengairan dan pemberantasan hama dan penyakit tanaman. Kegiatan pemeliharaan tanaman dilakukan dengan metode ceramah dan pendampingan 


\section{Hasil dan Pembahasan}

Pengabdian pada masyarakat tentang Pendampingan Masyarakat dalam Pengolahan Limbah Peternakan Sapi untuk Meningkatkan Pertumbuhan Tanaman bertujuan untuk: (1) melakukan pendampingan kepada anggota Kelompok Ternak Patuh Angen Dusun Ireng Daye Desa Jatisela dalam melakukan pengolahan limbah peternakan sapi menjadi bokashi (2) melakukan pendampingan kepada anggota Kelompok Ternak Patuh Angen dalam melakukan pemupukan tanaman khususnya tanaman cabai rawit dan kacang panjang menggunakan bokashi untuk meningkatkan pertumbuhan tanaman.

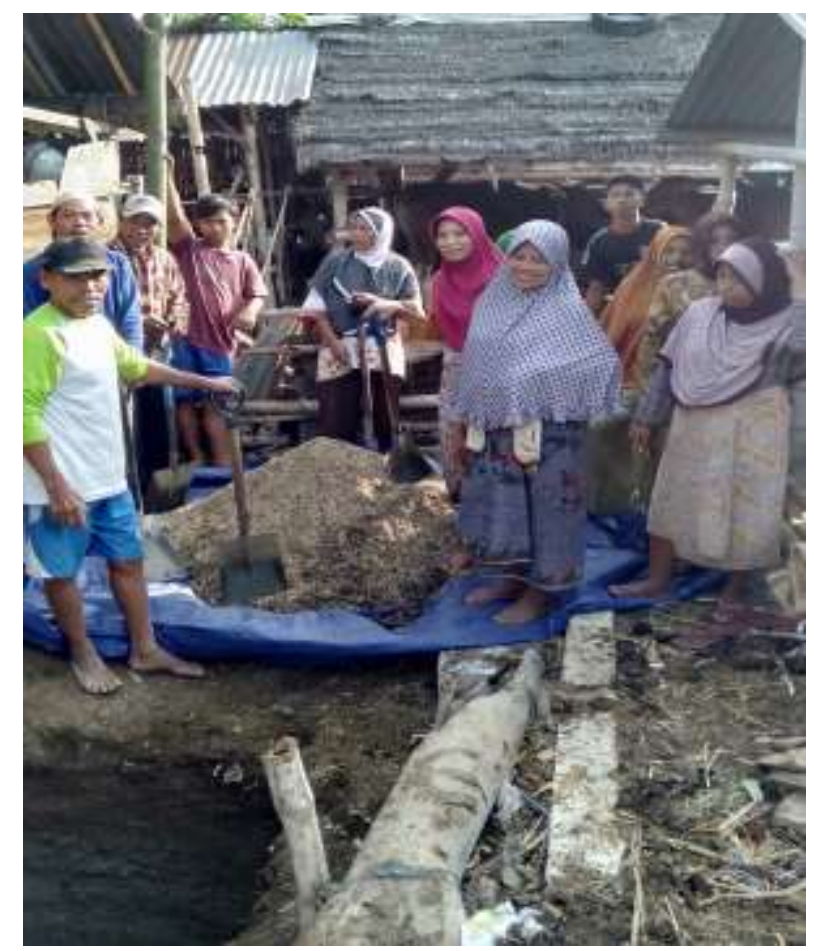

Gambar 1. Pembuatan bokashi oleh mitra

Dalam pelaksanaan kegiatan ini nampak bahwa masyarakat yang menjadi mitra kegiatan telaah mengikuti kegiatan dengan baik mulai dari sosialisasi kegiatan sampai pada saat penyampain materi pengabdian. Hal ini dapat dilihat dari banyaknya pertanyaan yang diajukan peserta yang terkait dengan materi yang disampaikan tim pelaksana pada saat diskusi. Selain itu pada saat praktek pembuatan bokashi semua peserta ikut bekerja secara aktif sehingga kegiatan paraktek pembuatan bokashi dapat berjalan lancar.

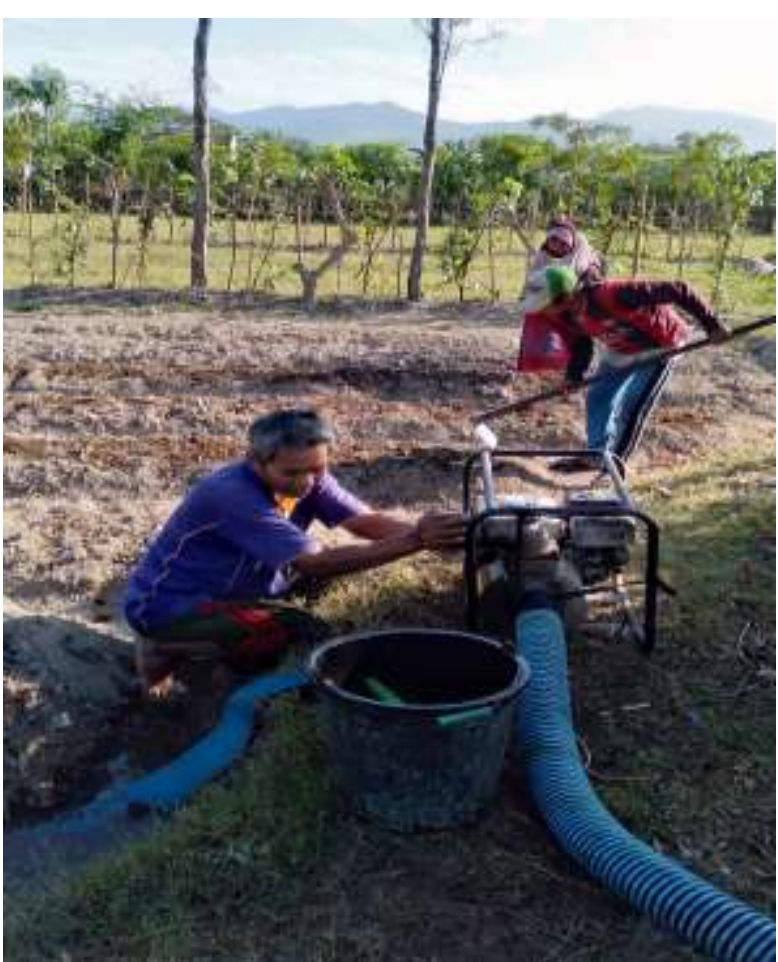

Gambar 2. Penggunaan bokashi pada lahan pertanian oleh mitra

Kegiatan pengabdian seperti ini sangat penting artinya bagi masyarakat sasaran karena melalui kegiatan ini mereka dapat memahami berbagai dampak yang mungkin timbul sebagai akibat banyaknya sampah yang dihasilkan kegiatan peternakan. Selanjutnya mereka diharapkan dapat melakukan pencegahan terhadap dampak tersebut dengan tidak membuang sampah disembarang tempat dan memanfaatkan sampah organik yang dihasilkan dari kegiatan usaha peternakan sebagai bahan baku pembuatan bokashi untuk meningkatkan pertumbuhan tanama yang dibudidayakan di pekarangan rumah, kebun dan lahan persawahan.

Setelah selesai pembuatan bokashi dengan bahan baku kotoran sapi, kegiatan dilanjutkan dengan penggunaan bokashi sebagai pupuk pada lahan pertanian untuk meningkatkan hasil panen tanaman. Pemupukan tanaman menggunakan bokashi dilakukan pada tanaman cabai rawit dan kacang panjang dengan langkah kerja sebagai berikut: (1) pembongkaran lahan menggunkan cangkul, (2) pembibitan tanaman cabai rawit, (3) pembuataan bedengan pada lahan yang akan ditanami tanaman cabai rawit dan kacang panjang, (4) pemberian bokashi pada bedengan dengan dosis 1,2 $\mathrm{kg}$ bokashi per $1 \mathrm{~m}^{2}$ lahan, (5) mencampur tanah 
pada bedengan dengan bokashi sampai tercampur secara merata, (6) menutup bedengan dengan mulsa plastik hitam perak, (7) menanam bibit cabai rawit yang sudah disiapkan, (8) penanaman kacang panjang, (9) melakukan perawatan tanaman cabai rawit dan kacang panjang, (10) panen tanaman cabai rawit dan kacang panjang

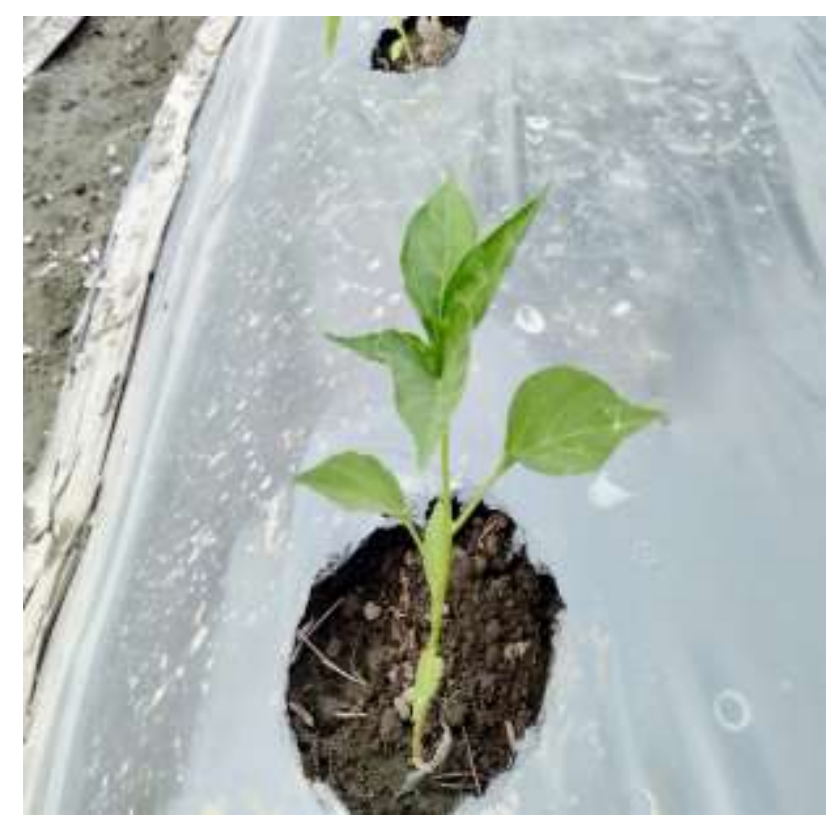

Gambar 3. Tanaman cabai rawit yang diberikan pupuk bokashi umur 3 hari

Upaya pemecahan masalah mitra yang dilakuan tim pelaksana pengabdian pada masyarakat mengacu pada hasil penelitian yang sudah dilkukan oleh tim pelaksanan dan penelitipeneliti yang lain. Hasil penelitian yang sudah dilakukan oleh Raksun dkk (2019) menyimpilkan bahwa aplikashi pupuk organik bokashi berpengaruh nyata terhadap perumbuhan dan hasil panen terong hijau. Raksun dan Santoso (2010) menyimpulkan bahwa pemberian bokashi pada lahan pertanian dapat meningkatkan produksi tomat. Demikian juga penelitian pada tanaman cabai rawit disimpulkan bahwa pemberian bokashi berpengaruh nyata terhadap produksi cabai rawit (Raksun dan Mertha, 2017). Selanjutnya disimpukan bahwa perlakuan pupuk bokashi jerami padi berpengaruh terhadap pertumbuhan dan produksi tanaman bawang merah. Perlakuan terbaik terdapat pada perlakuan $3 \mathrm{~kg} / \mathrm{plot}$ menghasilkan tinggi tanaman tertinggi $35,11 \mathrm{~cm}$, jumlah daun perumpun 10,44 helai, jumlah anakan perumpun 6,67 anakan, produksi per tanaman 43,39 $\mathrm{g}$ dan produksi per plot 1,09 kg (Mulyanti dkk,
2015). Aplikasi bokashi berpengaruh pada pertumbuhan vegetatif dan produksi rumput gajah. Bokashi 30 ton per hektar memberikan pertumbuhan vegetatif dan produksi rumput gajah tertinggi (Kusuma, 2013). Media terbaik untuk pertumbuhan semai eboni adalah pupuk organik EM bokashi karena media ini dapat meningkatkan solubilitas dan viabilitas hara dalam tanah dan memberikan pertumbuhan semai eboni yang optimal (Sumiasri dan Setyowati, 2006). Penggunaan bokashi EM4 memberikan pengaruh terhadap penambahan tinggi tanaman umur 3 dan 4 minggu setelah tanam, jumlah daun pada umur 2, 3 dan 4 minggu setelah tanam serta berat basah tanaman sawi (Ryan, 2010). Pemupukan bokashi dengan dosis 20 ton per hektar memberikan bobot gabah kering per hektar tertinggi (4,70 ton), jumlah anakan produktif tertinggi $(25,00)$ dicapai varietas cianjur (Mulyana dkk, 2011). Pemberian pupuk bokashi Eceng Gondok menunjukkan respon sangat nyata pada total produksi kedelai per plot (Hasibuan dkk, 2017). Terdapat interaksi antara pupuk organik bokashi dan pupuk nitrogen terhadap jumlah daun, pemberian pupuk organik bokashi 10 ton per hektar berpengaruh baik terhadap komponen kualitas bunga yaitu mampu menghasilkan tangkai bunga terpanjang dan jumlah kuntum bunga terbanyak (Farida dan Hamdani, 2003)..

Anggota Kelompok Ternak Patuh Angen Dusun Ireng Daye Desa Jatisela yang menjadi mitra kegiatan pengabdian pada masyarakat ini memilki ternak seperti kuda kambing dan sapi. Disekitar tempat tinggal mereka, terdapat banyak kotoran ternak dan sisa makanan ternak yang sampai saat ini masih belum dapat mereka olah menjadi suatu produk yang bermanfaat. Selama ini mereka menumpuk kotoran kernak disekitar kandang ternak dan membuangnya ke kali pada saat musim hujan. Kondisi tersebut merupakan faktor pendorong bagi peserta dalam mengikuti kegiatan ini. Melalui kegiatan ini, mereka memahami dan menyadari bahwa jika sampah yang mereka hasilkan dibuang disembarang tempat dapat menimbulkan berbagai dampak negatif bagi lingkungan. Dengan demikian mereka memiliki keinginan yang kuat untuk menjadi peserta kegiatan ini dan memanfaatkan sampah khususnya kotoran ternak yang ada disekitarnya sebagai bahan baku pembuatan bokashi serta memanfaatkan bokashi untuk meningkatkan pertumbuhan tanaman pada lahan pertanian yang mereka miliki. Selain itu 
pengolahan sampah peternakan menjadi bokashi dapat meningkatkan kebersihan lingkungan.

Pengolahan kotoran ternak menjadi bokashi di Dusun Ireng Daye Desa Jatisela dapat mencegah terjadinya pencemaran air pada kali-kali yang ada disekitar Dusun Ireng Daye. Demikian juga pengolahan sisa makanan ternak menjadi bokashi dapat mencegah terjadinya pencemaran udara oleh asap pembakaran sampah organik sisa makanan ternak. Selanjutnya penggunaan bokashi dalam pemupukan tanaman dapat mengurangi ketergantungan mitra terhadap penggunaan pupuk kimia sehingga biaya kegiatan usaha pertanian dapat dikurangi dan hasil panen tanaman dapat ditingkatkan. Selain itu bokashi yang dihasilkan mitra dapat dijual, sehingga pengolahan limbah petrnakan sapi menjadi bokashi dapat meningkatkan pendapatan anggota Kelompok Ternak Patuh Angen.

Faktor penghambat kegiatan ini adalah adanya kesibukan masyarakat dalam menyelesaaikan pekerjan rutinnya setiap hari seperti mengolah lahan pertanian dan mencari makanan ternak sehingga tim merasa kesulitan dalam menentukan waktu pelaksanaan kegiatan. Demikian juga tim pelaksana memiliki kesibukan dengan kegiatan perkuliahan di kampus Universitas Mataram. Kondisi ini menyebabkan terjadinya kesulitan dalam menentukan waktu pelaksanaan kegiatan. Tim pengabdian dan masyarakat harus membuat kesepakatan waktu pelaksanaan kegiatan dengan cermat agar waktu pelaksanaan kegiatan pengabdian tidak berbenturan dengan waktu perkuliahan di Universitas Mataram

Faktor penghambat lainnya adalah kurangnya air yang tersedia untuk mengairi lahan pertanian pada saat penanaman tanaman cabai rawit dan kacang panjang karena kegiatan pengabdian ini dilakukan pada musim kemarau. Hambatan ini dapat diatasi dengan menyewa mesin pompa air untuk memompa air yang ada pada sumur disekitar lahan pertanian yang dijadikan sebagai lahan penenaman tanaman uji coba penggunaan bokashi (cabai rawit dan kacang panjang).

\section{Kesimpulan}

Dari seluruh tahapan kegiatan mulai dari sosialisasi kepada kelompok masyarakat sasaran sampai dengan berakhirnya pelaksanaan kegiatan maka dapat disimpulkan bahwa: 1) Setelah berakhirnya kegiatan ini, anggota Kelompok Ternak Patuh Angen Dusun Ireng Daye Desa Jatisela Kecamatan Gunungsari Kabupaten Lombok Barat memiliki pengetahuan dan keterampilan tentang teknik pengolahan sampah organik khususnya kotoran sapi, kotoran kuda dan kotoran kambing menjadi bokashi. 2) Melalui kegiatan ini, anggota Kelompok Ternak Patuh Angen memiliki pengetahuan dan keterampilan tentang teknik pemupukan tanaman menggunakan bokashi. 3) Anggota Kelompok Ternak Patuh Angen memiliki respons yang sangat baik terhadap pelaksanaan kegiatan dan berkomitmen untuk moncoba memanfaatkan limbah yang dihasilkan dari usaha peternakan terutama kotoran ternak yang ada disekitarnya sebagai bahan baku pembuatan bokashi. Selanjutnya menggunakan bokashi untuk meningkatkan hasil panen tanaman yang ada di pekarangan maupun pada lahan pertanian yang mereka miliki.

\section{Ucapan Terima Kasih}

Termakasih yang sebesar-besarnya kami sampaikan kepada Rektor Universitas Mataram yang telah memfasilitasi penyediaan dana pelaksanaan pengabdian pada masyarakat. Terimakasih juga kami sampaikan kepada Ketua LPPM Universtas Mataram dan semua pihak yang telah membantu pelaksanaan pengabdian pada masyarakat ini.

\section{Daftar Pustaka}

Farida dan Hamdani, J.S. 2003. Pertumbuhan dan hasil bunga gladiol pada dosis pupuk organik bokashi dan nitrogen yang berbeda. Bionatura. Vol. 3 (2): 68 - 76

Hasibuan, S., Mawarni, R., Hendriandri, R. 2017. Respon Pemberian Pupuk Bokashi Ampas Tebu dan Pupuk Bokashi Eceng Gondok terhadap Pertumbuhan dan Produksi Tanaman Kedelai. Bernas Vol. 13 (2): 59 64

Indriani, Y. H. 2001. Membuat Kompos Secara Kilat. Penebar Swadaya. Jakarta.

Kusuma, M.E. 2013. Pengaruh Pemberian Bokashi terhadap Pertumbuhan dan Produksi Rumput 
Gajah (Penisetum purpureum). Ilmu Hewani Tropika. Vol 2 (2): 40 -45.

Mulyana, D., Sahidin dan A. Iqbal. 2011. Pengaruh Dosis Bokashi terhadap Pertumbuhan dan Hasil Tiga Varietas Padi. Agrin 15(1): p. 18 26

Mulyanti, S.S., U. Made dan I. Wahyudi. 2015. Pengaruh Pemberian Berbagai Jenis Bokashi terhadap Pertumbuhan dan Hasil Jagung Manis (Zea mays Saccarata). Agrotekbis 3(5) p. $592-601$

Raksun, A. dan D. Santoso, 2010. Pemanfaatan Bokashi Untuk Meningkatkan Pertumbuhan dan Produksi Tomat. Biologi Tropis. Vol 11(1): 44-50

Raksun, A. dan I.G. Mertha. 2017. Pengaruh Bokashi terhadap Produksi Cabawi Rawit. Biologi Tropis Vol. 17 (2): 45 - 50

Ryan, I. 2010. Respon Tanaman Sawi (Brassica juncea L.) Akibat Pemberian Pupuk NPK dan Penambahan Bokashi pada Tanah Asal Bumi Wonorejo Nabire. Agroforestri. Vol 5 (4): $310-319$

Sumiarsi, N dan Setyowati, 2006. Pengaruh beberapa Media TerhadapPertumbuhan Bibit Eboni (Diospyros celebica Bakh). Melalui Perbanyakan biji. Biodipersitas. Vol 7(3): 260-263. 